\title{
Adapting to climate change: a comparison of two strategies for dike heightening
}

\author{
Arjen Y. Hoekstra · Jean-Luc De Kok
}

Received: 29 June 2007/ Accepted: 29 December 2007/Published online: 1 March 2008

(C) The Author(s) 2008

\begin{abstract}
In the Netherlands the current dike design policy is to design flood defence structures corresponding to an agreed flooding probability with an extra safety board of at least $0.5 \mathrm{~m}$. For river dikes a return period of 1,250 years is used to determine the design water levels. A problem with this strategy is that it builds on assumptions with regard to the intrinsically uncertain probability distributions for the peak discharges. The uncertainty is considerable and due to (1) the measuring records that are limited to about 100 years and (2) the changing natural variability as a result of climate change. Although the probability distributions are regularly updated based on new discharge data the nature of the statistics is such that a change in the natural variability of the peak discharge affects the probability distribution only long after the actual change has happened. Here we compare the performance of the probabilistic dike design strategy with the older strategy, referred to as the 'self-learning dike'. The basic principle of the latter strategy is that the dike height is kept at a level equal to the highest recorded water level plus a certain safety margin. The two flood prevention strategies are compared on the basis of the flooding safety over a 100-year period. The Rhine gauge station at Lobith serves as case study. The results indicate that the self-learning dike performs better than the probabilistic design in terms of safety and costs, both under current and climate change conditions.
\end{abstract}

Keywords Flood defence $\cdot$ Uncertainties $\cdot$ Climate change $\cdot$ Adaptation $\cdot$ Rhine

\section{Introduction}

After the 1953 flood catastrophe in the Southwest of the Netherlands, a probabilistic approach was chosen for the design of coastal flood defence works in the Netherlands (Van Danzig 1956; Vrijling 2001). From the 1980s onwards this approach was adopted for the design of the dikes in general (Vrijling 2001). The current approach is based on a design

A. Y. Hoekstra $(\bowtie) \cdot$ J.-L. De Kok

Twente Water Centre, University of Twente, P.O. Box 217, 7500 AE Enschede, The Netherlands e-mail: a.y.hoekstra@utwente.nl 
water level corresponding to the return period for overtopping of the dikes, which is increased with a safety board of at least $0.5 \mathrm{~m}$ (TAW 1985; MTPWWM 2005a; Van der Most et al. 2005). The exceedance frequencies are differentiated over the country. Roughly, in the western part of the country an exceedance frequency of once per 10,000 years is applied; for coastal flood defence works in the south-western and northern parts of the country an exceeding frequency of once in 4,000 years is maintained; for river dikes it is once in 1,250 years and in the intermediate area that is potentially affected by both coastal and river floods a return period of 2,000 years is used.

By law the design water levels are re-evaluated every 5 years to deal with uncertainties with respect to the actual peak discharge variability and to respond to climate change. A problem encountered here is that the statistical distributions for the peak discharge are extrapolations derived from limited time series of discharge data. The knowledge about discharges and water levels with a return period of 1,250 years is limited because historic data are available for a 100-year period only. Furthermore, the volume and variability of peak discharges are subject to change due to factors such as climate change and changing upstream flow conditions. Due to climate change the peak flows in the lower Rhine corresponding to return times of 100-1,000 years are expected to increase by $5-8 \%$ over the next 50 years (Middelkoop et al. 2001). As an extreme scenario the design discharge at Lobith could increase from 16,000 to $20,000 \mathrm{~m}^{3} \mathrm{~s}^{-1}$ in the year 2100 (Middelkoop and Kwadijk 2001). In the probabilistic design a change in the discharge regime will only lead to a different design long after the change took place, even if the discharge statistics are regularly updated. It is therefore inherent to this strategy that the actions taken to reduce the flood risk are not anticipatory but following.

Meanwhile, in the Netherlands the awareness is growing that the social-economic development and changes in the physical conditions during the second half of the 20th century call for a more balanced flood defence strategy, which addresses not only the probability of flooding but also the consequences if flooding would occur (Ten Brinke and Bannink 2004; MTPWWM 2005a; Van Manen and Brinkhuis 2005). Notwithstanding this shift in thinking-from reducing exceedance probability towards reducing the flooding risk as a whole-dikes will remain a key element of flood defence management in the Netherlands. In this context, the current paper evaluates the usefulness of the probabilistic dike design policy against the background of the older design philosophy, which was to apply a safety margin on top of the highest water level ever recorded. We refer to this older design philosophy by the term 'self-learning dike', where 'self-learning' refers to the fact that dike adjustments immediately follow actual extreme flood levels. Metaphorically speaking, the dike learns through monitoring actual water levels and adapting according to a simple rule, without applying any statistics.

A comparison between the probabilistic flood prevention strategy and the self-learning strategy has been carried out for the case of the border gauge Lobith of the Rhine river. The endangered dike ring area 48 "Rijn and IJssel" has a total dike length of $57 \mathrm{~km}$. In case of flooding the worst case estimate of the flood damage is 6.8 billion euro (Eijgenraam 2005). The historic discharge time series for the period 1901-1998 (Parmet et al. 2001) are taken as a basis for estimating the probability of high discharges. This forms the starting point for simulating future peak discharges over a 100-year period. The two dike heightening strategies are compared for three different scenarios for the peak discharge statistics. The dike strategies are: 
A. The probabilistic design with a safety board of $0.5 \mathrm{~m}$ and adaptation of the discharge statistics every 5 years and

B. The self-learning dike with adaptation if the water level exceeds the actual dike height minus a safety margin.

The three scenarios differ in terms of the statistical distribution applied when generating the future peak discharges:

1. Current peak discharge statistics without including uncertainty;

2. Peak discharge statistics with uncertainty included;

3. Gradual climate change trend with slowly increasing peak discharges.

The results of the simulations are compared on the basis of the average number of dike overtopping instances, the average number of times the dike has to be heightened, and the total extra height added to the initial dike height during the 100-year simulation.

\section{Methodology}

\subsection{Statistical analysis of peak discharges}

The comparison of the different dike heightening mechanisms is based on extension of the historical discharge data for the gauge station at Lobith. A time series of the yearly maximum discharges (Fig. 1) is available for the period 1901-1998 (Parmet et al. 2001). The complete time series has been homogenised so as to represent the river condition of 1977 (Lorenz and Kwadijk 1999; Parmet et al. 2001).

The homogenised peak discharge data have been used to derive the parameters for the Gumbel Extreme Value distribution (Bury 1999; Shaw 2002) with the cumulative probability distribution:

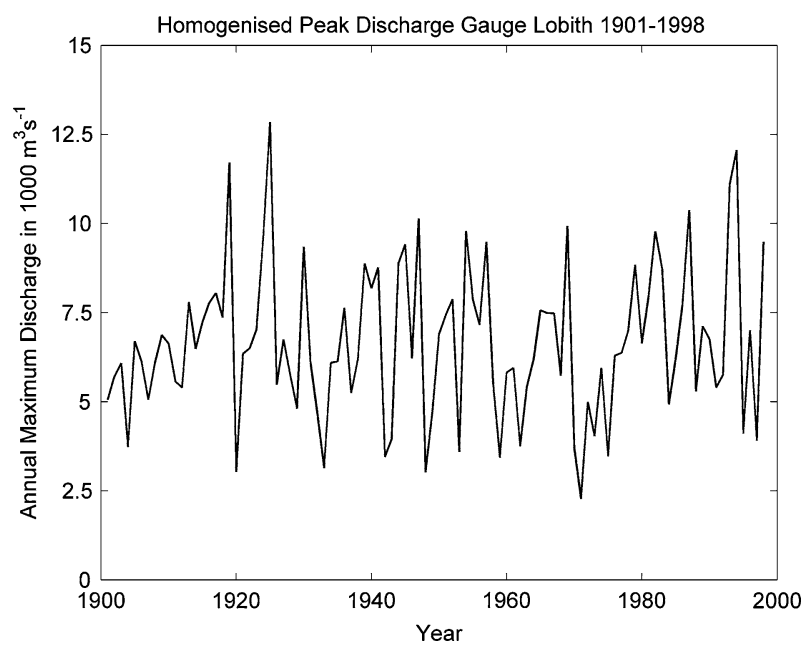

Fig. 1 Homogenised peak discharge data for the period 1901-1998 (Parmet et al. 2001) for the gauge station Lobith of the Rhine River 


$$
F(Q)=\operatorname{Pr} o b\left(q_{\max } \leq Q\right)=\exp (-\exp (-b(Q-a))
$$

where $Q$ is the peak discharge in $\mathrm{m}^{3} \mathrm{~s}^{-1}$ and $a$ and $b$ are the moment estimators for the parameters of the Gumbel distribution (Bury 1999; Shaw 2002):

$$
\begin{gathered}
a=\mu-\frac{\gamma}{b} \quad(\gamma=0.5772) \\
b=\frac{\pi}{\sigma \sqrt{6}}
\end{gathered}
$$

where $\mu$ and $\sigma^{2}$ are the sample mean and variance. The stationary Gumbel distribution is justified here because statistical analysis using the Spearman ranking test did not reveal a significant trend in the historic discharge time series. In addition application of the probability plot correlation test statistic (Stedinger et al. 1993) to the discharge data proved that the historic discharge data could be described with a Gumbel distribution. For the simulated extension of the peak discharge time series in the first two scenarios there is no trend as well. For the scenario with a gradual climate change the probability distribution becomes non-stationary (Khaliq et al. 2006). In this case the Gumbel parameters $a$ and $b$ are made time dependent by means of multiplication with a common factor, which ensures the chosen design discharge is reached after 100 years.

For the initial year of the simulation the values $a=5,170 \mathrm{~m}^{3} \mathrm{~s}^{-1}$ and $b=6.584 \times 10^{-4}$ $\mathrm{m}^{-3} \mathrm{~s}^{-1}$ were determined from the rescaled discharge data to ensure that the 1,250-year design discharge corresponded to the value of $16,000 \mathrm{~m}^{3} \mathrm{~s}^{-1}$ at Lobith, which was agreed upon in 2001 (MTPWWM 2005b). The variance of these two parameters can be approximated by:

$$
\operatorname{Var}(a) \approx \frac{1.16781}{N b^{2}} \quad \operatorname{Var}(b) \approx \frac{1.10001 b^{2}}{N}
$$

where $N$ is the peak discharge sample size (Bury 1999).

The return period for a peak discharge $Q$ is then given by

$$
T(Q)=\frac{1}{P(Q)}=\frac{1}{1-\exp (-\exp (-b(Q-a))}
$$

Figure 2 shows the return period for the fitted Gumbel distribution with the $95 \%$ confidence limits against the peak discharge data after rescaling, represented by the Gringorten plotting positions according to (Shaw 2002):

$$
\operatorname{Pr} o b\left(Q>q_{i}\right)=\frac{r_{i}-0.44}{N+0.12}
$$

where $r_{i}$ is the rank of the peak discharge $q_{i}$ in year $i$, and $N$ is the length of the time series.

The significance of the uncertainty as shown in Fig. 2 is widely acknowledged (Parmet et al. 2001; Shaw 2002; MTPWWM 2005a). Recognition of this uncertainty is a key motivation for the self-learning dike management strategy.

\subsection{Simulation of overtopping}

Once the representative Gumbel probability distribution was established the parameters were used to simulate an artificial 100-year time series following the historic period. For each year the new discharge is simulated by: 


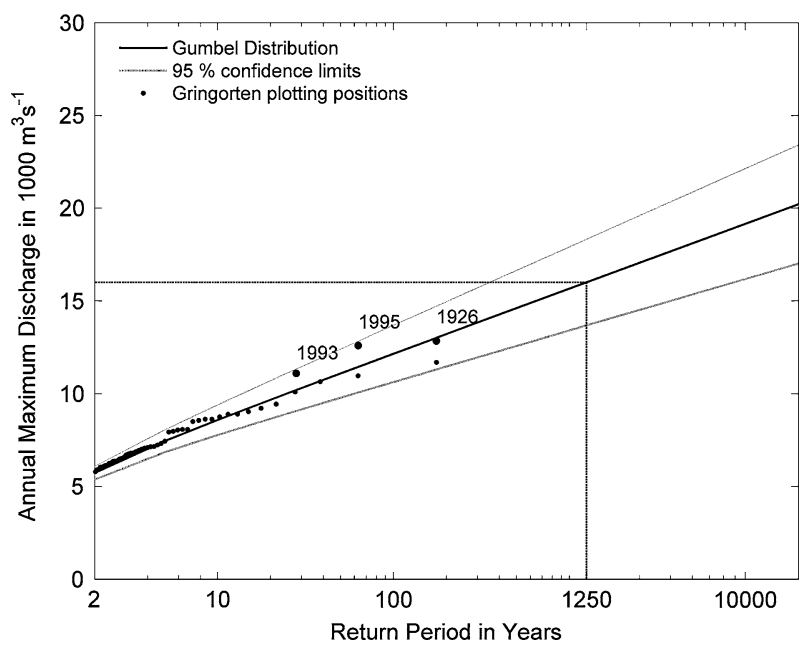

Fig. 2 Fitted Gumbel Extreme value distribution with a 1,250-year design discharge of $16,000 \mathrm{~m}^{3} \mathrm{~s}^{-1}$. The 1926 flood and recent peak discharges of 1993 and 1995 are indicated separately

$$
Q(t)=F^{-1}\left(x_{t}\right)
$$

where $Q(t)$ is the discharge in year $t, F^{-1}(x)$ the inverse of the cumulative distribution function of Eq. 1 that is determined from the extended discharge record, and $x_{t}$ a random uniform number in the range $[0,1]$.

To obtain a reliable estimate of the probability of overtopping during the 100 -year period the simulations were repeated $10^{5}$ times. This number of iterations ensures that the values of $\mu$ and $\sigma$ for the simulated discharge approach the parameters of the Gumbel distribution within less than $1.5 \%$. For any year the water level corresponding to the discharge is determined from the known stage-discharge relationship (Fig. 3) for the gauge station at Lobith, which is an extrapolation of the stage-discharge relationship based on Schielen (2007) and Van den Brink et al. (2007). Obviously, the extrapolation of the stagedischarge relationship for extreme discharges, which have not been observed so far, is subject to some uncertainty and will influence the quantitative outcomes of the analysis. For the conclusions of this study, however, the shape of the stage-discharge relationship is not relevant. This water level is first compared with the existing dike height to determine whether overtopping occurs. Depending on the dike management strategy chosen the water level is also used to adapt the dike when necessary (see Sect. 3). The results of the simulations are used to determine the average probability of overtopping during a 100-year period for each combination of the dike strategies and discharge scenarios.

\subsection{Costs of dike heightening versus expected flood damage}

Although we are primarily interested in this paper in the safety provided by both dike strategies, measured by the expected number of overtopping instances in the coming century, we also estimated for both strategies the costs of dike heightening and the prevented flood damage. The investment costs of heightening the dikes along the complete 57$\mathrm{km}$ length of the dike for dike ring 48 have been obtained by extrapolation of the 




Fig. 3 Stage-discharge relationship for the Rhine gauge station at Lobith based on Schielen (2007) and Van den Brink et al. (2007)

investment costs given by Eijgenraam (2005, Table 3.6 and Appendix C). For dike ring 48 the fixed investment costs are $0.5 \times 10^{6}$ euro, whereas the variable investment costs are $1.2 \times 10^{6}$ euro per km length of dike for an extra dike height of $50 \mathrm{~cm}, 1.8 \times 10^{6}$ euro per $\mathrm{km}$ length of dike for an extra dike height of $75 \mathrm{~cm}$, and $3.0 \times 10^{6}$ euro per km length of dike for an extra dike height of $100 \mathrm{~cm}$, respectively.

\section{Experiments}

\subsection{Dike heightening strategies}

The two dike heightening strategies differ in the rule that governs the heightening of the dike. The probabilistic approach is based on the Design Flood Level (DFL), which is the water level corresponding to a flood return time of 1,250 years, plus a safety board of $0.5 \mathrm{~m}$. The DFL is calculated on the basis of the historic record 1901-1998, and updated every 5 years by determining again the peak discharge probability distribution with the additional discharge data added to the existing time series. In the self-learning design strategy the dike height is compared with the highest water level that occurred so far. If this water level exceeds the existing dike height minus a safety margin $s$, the dike is heightened to the water level plus this safety margin. Obviously, a larger safety margin leads to a safer but more expensive dike design. For this analysis the safety margin has been taken equal to the dike height for the probabilistic dike design (including the safety board) minus the largest historic water level. This ensures that the initial dike height is identical for both strategies.

Currently the design flood level for a 1,250-year flood near Lobith is $17.93 \mathrm{~m}$ above NAP (based on the Gumbel distribution and stage-discharge relationship used in this 
study). With a safety board of $0.5 \mathrm{~m}$, this means that the dike height should be $18.43 \mathrm{~m}$ above NAP according to the current probabilistic strategy. The highest historic discharge at Lobith is, taking the homogenisation that was mentioned into account, $12.849 \mathrm{~m}^{3} \mathrm{~s}^{-1}$ and was observed in 1926 (Parmet et al. 2001). This discharge corresponds to a water level of $16.59 \mathrm{~m}$ above NAP, based on the stage-discharge relationship and discharge statistics used here. With the requirement of identical initial dike heights for both strategies this implies that the safety margin $s$ of the self-learning dike must be $1.84 \mathrm{~m}$, which seems reasonable. With this safety margin an overnight shift from the current probabilistic strategy to the self-learning strategy will not imply that the dikes need to be heightened immediately.

\subsection{Discharge scenarios}

The performance of the two dike heightening strategies has been evaluated based on three different discharge scenarios: a scenario without uncertainty in the probability distribution function, a scenario including uncertainty and a scenario with a gradual increase of the design discharge to reflect the effect of climate change.

\subsubsection{Scenario 1: Current peak discharge variability without uncertainty}

This scenario is represented by the central estimate of the Gumbel distribution of the peak discharges as shown in Fig. 2. The scenario consists of a 100-year time series of randomly drawn discharge values based on Eq. 6, ignoring uncertainty in the probability distribution function. This simulation is repeated $10^{5}$ times, after which the average number of times that the dike overtops during 100 years is obtained.

\subsubsection{Scenario 2: Current peak discharge variability with uncertainty}

The second scenario accounts for the uncertainty in the peak discharge statistics, as shown by the $95 \%$ confidence interval in Fig. 2 . The scenario is identical to scenario 1, but first the Gumbel parameters $a$ and $b$ are drawn from a normal distribution with a mean and variance according to Eqs. 2,3. For every year in each simulation, a random set of values for $a$ and $b$ is taken as input to the Gumbel distribution that is subsequently used to draw a discharge from. This scenario simulates the uncertainty in the probability distribution but without a systematic change in the discharge range that can be attributed, for example, to climate change.

\subsubsection{Scenario 3: Gradual climate change}

Here the parameters of the Gumbel distribution are increased gradually up to a value corresponding to a design discharge of $18,000 \mathrm{~m}^{3} \mathrm{~s}^{-1}$ for the year 2100 . This value is considered to be the theoretical maximum discharge for Lobith (MTPWWM 2005b). This scenario simulates the effect of climate change on the discharge probability distribution, leading to a higher probability of all peak discharges. The change is introduced as a linear increase from the initial year onwards. 


\section{Results}

The safety performance and necessity to heighten the dikes of both strategies has been recorded over the period of 100 years (Table 1). The results indicate that, on average, the self-learning dike performs better in terms of safety and requires less adaptations of the dike height. The average extra height per adaptation and total extra height after 100 years, however, are larger for the self-learning dike. The expected number of overtopping instances is lower in the case of the self-learning dike in all three scenarios, but the improvement is largest in case of the climate change scenario, in which the self-learning dike shows a $21 \%$ reduction of overtopping instances when compared to the probabilistic dike. The reason is that the self-learning dike responds faster to climate change than the probabilistic dike.

Table 2 shows the discounted costs and expected flood damage for both dike strategies, based on the average of 100,000 simulations. The average flood damage is based on a $2 \%$ annual economic growth rate as used by Eijgenraam $(2005,2006)$. The Net Present Value is based on an effective discount rate of $4 \%$ (Eijgenraam 2005, 2006) and determined from:

$$
\mathrm{NPV}=\sum_{t=1}^{100} \frac{C(t)+D(t)}{(1+r)^{t}}
$$

where $C(t)$ are the investment costs in year $t, D(t)$ is the flood damage in year $t$ and $r$ is the discount rate. For the probabilistic design the fixed investment costs are larger than for the self-learning dike, whereas the variable costs of dike heightening are smaller. As expected

Table 1 Average performance of the probabilistic (A) and self-learning (B) dike heightening strategy for the three discharge scenarios over the 100-year simulation period

\begin{tabular}{|c|c|c|c|c|c|c|}
\hline & \multicolumn{2}{|c|}{$\begin{array}{l}\text { Standard } \\
\text { discharge scenario }\end{array}$} & \multicolumn{2}{|c|}{$\begin{array}{l}\text { Discharge scenario } \\
\text { with uncertainty }\end{array}$} & \multicolumn{2}{|c|}{$\begin{array}{l}\text { Discharge scenario } \\
\text { with climate change }\end{array}$} \\
\hline & A & $\mathrm{B}$ & A & B & A & B \\
\hline Number of dike overtoppings & 0.024 & 0.021 & 0.034 & 0.030 & 0.047 & 0.037 \\
\hline Number of adaptations & 2.13 & 1.00 & 2.40 & 1.09 & 3.62 & 1.40 \\
\hline Extra height per adaptation (m) & 0.07 & 0.48 & 0.07 & 0.51 & 0.07 & 0.51 \\
\hline Total extra height after 100 years (m) & 0.14 & 0.48 & 0.17 & 0.55 & 0.24 & 0.71 \\
\hline
\end{tabular}

Table 2 Comparison of the average costs of dike heightening and average expected flood damage for both dike strategies for the three scenarios

\begin{tabular}{|c|c|c|c|c|c|c|}
\hline & \multicolumn{2}{|c|}{$\begin{array}{l}\text { Standard } \\
\text { discharge } \\
\text { scenario }\end{array}$} & \multicolumn{2}{|c|}{$\begin{array}{l}\text { Discharge } \\
\text { scenario with } \\
\text { uncertainty }\end{array}$} & \multicolumn{2}{|c|}{$\begin{array}{l}\text { Discharge } \\
\text { scenario with } \\
\text { climate change }\end{array}$} \\
\hline & A & $\mathrm{B}$ & A & B & A & B \\
\hline Fixed costs of dike heightening in $10^{6} €$ & 22.66 & 8.15 & 24.59 & 8.97 & 27.05 & 9.80 \\
\hline Variable costs of dike heightening in $10^{6} €$ & 4.63 & 17.46 & 5.35 & 21.30 & 5.66 & 21.91 \\
\hline Flood damage over 100 years in $10^{6} €$ & 74.83 & 69.46 & 107.19 & 98.78 & 121.87 & 106.11 \\
\hline Average costs per dike height adaptation in $10^{6} €$ & 12.81 & 25.54 & 12.49 & 27.89 & 9.04 & 22.60 \\
\hline Total expected costs in $10^{6} €$ & 102.11 & 95.07 & 137.13 & 129.06 & 154.58 & 137.82 \\
\hline Total expected costs in $10^{6} €$ without dike heightening & \multicolumn{2}{|c|}{84.84} & \multicolumn{2}{|c|}{122.77} & \multicolumn{2}{|c|}{146.54} \\
\hline
\end{tabular}


the flood damage due to dike overtopping is smaller for the self-learning dike due to the higher safety level. The total expected costs (sum of investment costs of dike heightening and flood damage) are always a bit smaller for the self-learning dike. Compared with the damage incurred without dike heightening the total costs are only lower for the selflearning dike for the scenario with climate change.

Figure 4 shows the year-by-year development of the average costs of dike heightening, number of dike overtopping instances, flood damage and total expected costs for both dike strategies for the climate change scenario with a gradual increase of the design discharge to $18,000 \mathrm{~m}^{3} \mathrm{~s}^{-1}$. For the self-learning dike the average costs of dike heightening show no trend, whereas for the probabilistic design the costs decrease first due to the increased safety level with corresponding higher dikes, after which the costs increase again due to the change in the discharge statistics as a result of climate change.
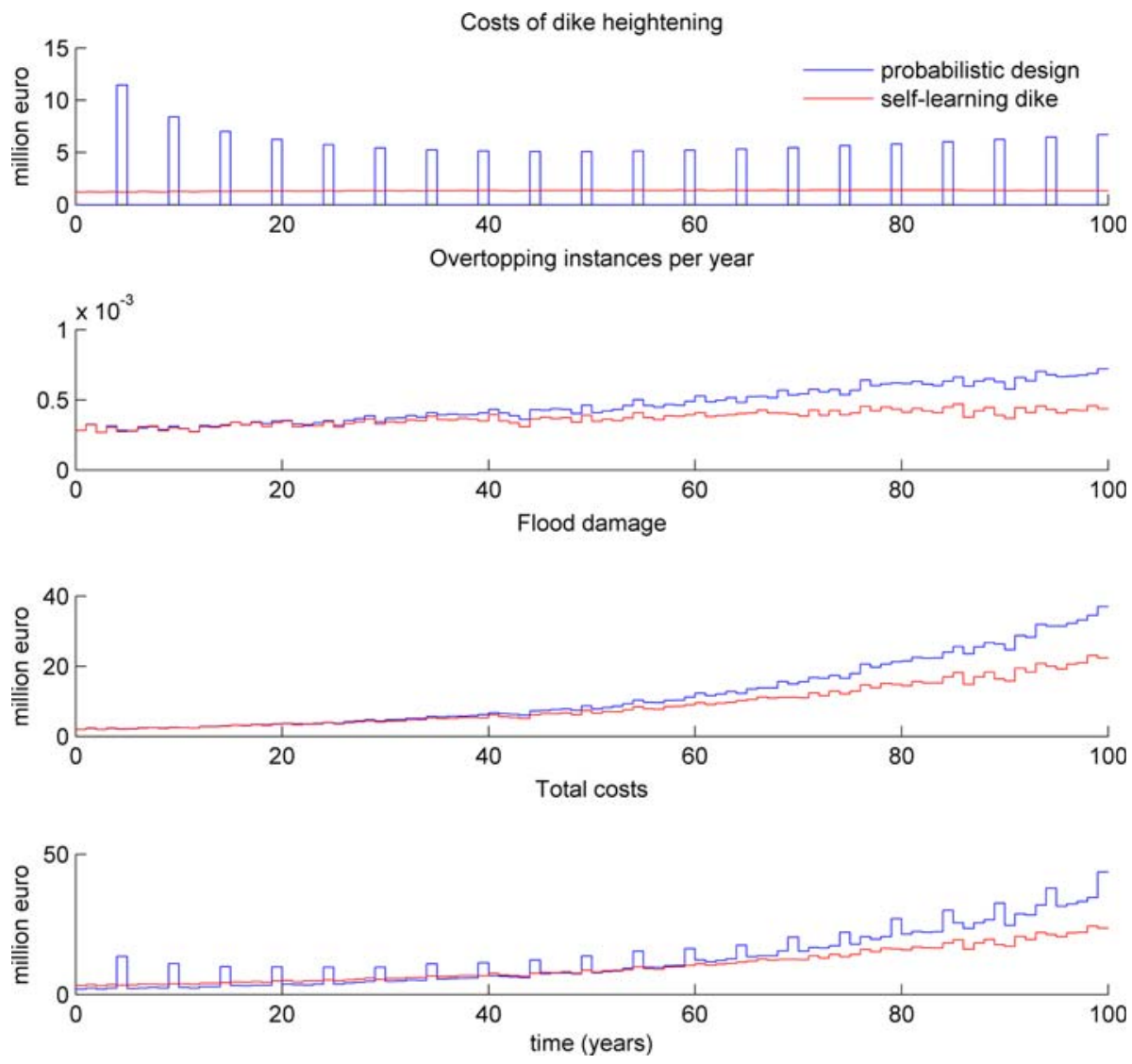

Fig. 4 Average investment costs of dike heightening, number of overtopping instances, flood damage and total expected costs for the probabilistic strategy (blue) and the self-learning dike (red) over the 100-year simulation period. The discharge statistics correspond to a gradual increase of the design discharge from 16,000 to $18,000 \mathrm{~m}^{3} \mathrm{~s}^{-1}$ (scenario 3) 


\section{Discussion}

Although flood defence policy is shifting towards a risk-oriented approach, in which both the probability of a flood and its consequences are accounted for (Ten Brinke and Bannink 2004; MTPWWM 2005a), we only considered dike overtopping as a failure mechanism, with dike heightening as a measure. The reason is that the outcomes of a full risk analysis are very sensitive to the level of spatial detail of the analysis and the extent to which all failure mechanisms are included, and is still subject to considerable uncertainty (Hoekstra 2005). Heightening dikes will remain one of the key measures available to risk managers, which makes it important to examine which approach can most effectively deal with the uncertainties inherent to river peak discharges.

The effectiveness of the probabilistic dike design strategy has been compared with the self-learning dike strategy on the basis of the average number of overtopping instances over a 100-year period. The results of the simulations clearly indicate that the safety level and total expected costs of the self-learning dike are somewhat lower than for the probabilistic design, although the self-learning dike requires larger adaptations.

Under conditions of uncertain or gradually changing discharge statistics, the average safety performance of the self-learning dike is also better than for the dike based on a probabilistic design. Uncertainties with respect to the current and future peak discharge conditions reduce the effectiveness of the probabilistic dike design. Hence, the advantage of the self-learning dike is larger if, for example, the natural variability of peak discharges in a river is higher (because this results in larger uncertainties in the peak discharge probability distribution function). The benefit of the self-learning dike is also higher if the natural discharge statistics are likely to change but difficult to predict (as in the case of climate change). The underlying reason is that the self-learning dike responds faster to climate change than the probabilistic dike. The Rhine is one of the best studied rivers in the world and not one with a particularly high variability of peak discharges (compared to other rivers in the world), so it is likely that the results found in this study with the Rhine at Lobith as an example will also be applicable to other rivers. The exact outcomes of the simulations depend on the shape of the stage-discharge relationship and the peak discharge statistics for the case study at hand, as well as the probabilistic design criterion.

In case of another river or river location, a different stage-discharge relationship will apply and the volumes and variability of the historically recorded peak discharges will be different. This will result in a different design flood level for the probabilistic approaches and another $Q_{\max }$ and $H_{\max }$ as design criterion for the self-learning approach. Without a change of the discharge statistics a steeper stage-discharge relationship results more frequently in exceedance of the criterion for dike heightening, and hence requires a smaller safety margin for the self-learning strategy to obtain the same level of flood safety.

A lower safety standard (for example overtopping once in 250 years) or the absence of a safety board requirement will result in a lower initial dike height for the probabilistic strategy. In this case the relative performance of the self-learning dike will increase because the dike height does not depend on the probability of overtopping. For a higher safety standard the opposite will occur.

If river engineering measures aimed at increasing the discharge capacity of the river are implemented, this will — given a certain peak discharge — result in a lower water level than before the measure was implemented. For the self-learning dike this means that the highest peak discharge recorded before the measure was implemented can be adjusted downwards in correspondence to the expected water-level reducing effect of the measure. 
The effect of a change in the peak discharge statistics on the performance of the selflearning dike strategy is already clear from the comparison of the results for scenarios 2 and 3 with the results for scenario 1. More frequent peak discharges and higher peak discharges act in favour of the self-learning approach. On the other hand, the differences with the probabilistic strategies will be smaller for a river with a more moderate discharge regime. The presence of uncertainty in the discharge regime is widely acknowledged and is the key motivation for the self-learning dike strategy. Accepting that there are intrinsic uncertainties related to peak discharges, the self-learning dike strategy is to increase the dike height in response to actual peak water levels rather than to act based on the outcome of a probabilistic analysis that excludes such uncertainties.

Other advantages of the self-learning dike are that its rule for response is very simple and that it requires a record of the peak water levels only. The self-learning dike design does not depend on uncertainties in the extrapolation of discharge statistics, nor on the use of an uncertain stage-discharge relationship. This contrasts with the probabilistic approach which requires advanced methods of calculation in addition to the actual monitoring of water levels; although the idea of the probabilistic approach-guaranteeing a predefined safety level-is attractive, the uncertainties in the actual and future peak discharge statistics make it practically impossible to actually guarantee that safety level. Although the simpler approach of the self-learning dike does not give a pre-defined guarantee of a fixed safety standard, it provides transparency and a higher level of safety in practice. Besides, in terms of safety communication towards the protected population the rule of the selflearning dike seems to be fairer: it is clearly visible how high the dike should be (a safety margin beyond the highest recorded water level) and it does not promise more than it can fulfil. The probabilistic strategy, on the contrary, suggests a certain safety level (in terms of the exceedance probability), but one is not able to guarantee this due to the uncertainties in the calculations and the slow response to changes in the discharge regime.

Acknowledgements The authors would like to thank Dr. Martijn J. Booij of the University of Twente for useful suggestions with regard to the hydrological aspects of this work and Dr. Ralph M J Schielen for providing the stage-discharge relationship used in this study.

Open Access This article is distributed under the terms of the Creative Commons Attribution Noncommercial License which permits any noncommercial use, distribution, and reproduction in any medium, provided the original author(s) and source are credited.

\section{References}

Bury K (1999) Statistical distributions in engineering. Cambridge University Press, Cambridge, United Kingdom

Eijgenraam CJJ (2005) Veiligheid tegen overstromen - Kosten-batenanalyse voor Ruimte voor de Rivier, deel 1 (Flood safety - Cost-benefit analysis for Room for the River, part 1). CPB Document No. 82., Netherlands Bureau for Economic Policy Analysis (CPB), The Hague, The Netherlands. http://www.cpb.nl/nl/pub/cpbreeksen/document/82/doc82.pdf. Cited 3 Oct 2007

Eijgenraam CJJ (2006) Optimal safety standards for dike-ring areas. CPB Discussion Paper No. 62., Netherlands Bureau for Economic Policy Analysis (CPB), The Hague, The Netherlands. http://www.cpb.nl/eng/pub/cpbreeksen/discussie/62. Cited 13 June 2007

Hoekstra AY (2005) Generalisme als specialisme: Waterbeheer in de context van duurzame ontwikkeling, globalisering, onzekerheden en risico's (Generalism as specialism: water management in the context of sustainable development, globalization, uncertainties and risks). Inaugural address, University of Twente, Enschede, The Netherlands. In Dutch. http://www.water.utwente.nl/publs/downloads/ Hoekstra.2005.UT.Oratie.pdf. Cited 13 June 2007 
Khaliq MN, Ouarda TBMJ, Ondo JC, Gachon P, Bobée B (2006) Frequency analysis of a sequence of dependent and/or non-stationary hydro-meteorological observations: a review. J Hydrol 329(3-4): $534-552$

Lorenz NN, Kwadijk JCJ (1999) Onderzoek 1/1250 afvoer bij Lobith. Representativiteit meetreeks, verdelingsfuncties en statistische extrapolatie (Investigation of the 1250-year discharge at Lobith. Representativeness of the discharge record, distribution functions and statistical extrapolation). WL I Delft Hydraulics, Delft, The Netherlands. In Dutch.

Middelkoop H, Kwadijk JCJ (2001) Towards integrated assessment of the implications of global change for water management - the Rhine experience. Phys Chem Earth PT B 26(7-8):553-560

Middelkoop H, Daamen K, Gellens D, Grabs W, Kwadijk JCJ, Lang H, Parmet BWAH, Schädler B, Schulla J, Wilke K (2001) Impact of climate change on hydrological regimes and water resources management in the Rhine basin. Clim Change 49:105-128

MTPWWM (2005a) Veiligheid Nederland in Kaart - Tussenstand onderzoek overstromingsrisico's (Mapping the Safety of The Netherlands - Intermediate Status of the Examination of Flood Risks). Ministry of Transport, Public Works and Water Management, The Hague, The Netherlands. In Dutch. http://www.projectvnk.nl. Cited 13 June 2007

MTPWWM (2005b) Planologische Kernbeslissing Ruimte voor de Rivier - Deel 3 - Hoofdstuk 4 - Strategische Beleidskeuzen (Key National Spatial Planning Decision Room for the River - Part 3 - Chapter 4 - Strategic Policy Decisions). Ministry of Transport, Public Works and Water Management, The Hague, The Netherlands. In Dutch. http://www.ruimtevoorderivier.nl. Cited 13 June 2007

Parmet BWAH, Van de Langemheen W, Chbab EH, Kwadijk JCJ, Diermanse FLM, Klopstra D (2001) Analyse van de maatgevende afvoer van de Rijn te Lobith (Analysis of the design discharge of the River Rhine at Lobith), RIZA report 2002.012. Ministry of Transport, Public Works and Water Management, Directorate Rijkswaterstaat, Institute for Inland Water Management and Waste Water Treatment (RIZA), Arnhem, The Netherlands. In Dutch. http://www.rijkswaterstaat.nl/rws/riza/home/ publicaties/rapporten/2002/2002_012.htm. Cited 13 June 2007

Schielen RMJ (2007)_Private communication Ministry of Transport, Public Works and Water Management, Directorate Rijkswaterstaat, Institute for Inland Water Management and Waste Water Treatment (RIZA).

Shaw EM (2002) Hydrology in Practice, 3rd edn. Stanley Thornes Publ. Ltd., United Kingdom

Stedinger JR, Vogel RM, Foufoula-Georgiou E (1993) Frequency analysis of extreme events. In: Handbook of hydrology, Chapter 18, McGraw-Hill, USA, pp 18.27-18.28

TAW (1985) Leidraad voor het ontwerpen van rivierdijken (Guideline for the design of river dikes), Technical Advisory Committee for Flood Defenses, Delft, The Netherlands. In Dutch

Ten Brinke WBM, Bannink BA (2004) Dutch dikes and risk hikes. A thematic policy evaluation of risks of flooding in the Netherlands, RIVM Report 500799002. National Institute for Public Health and the Environment (RIVM), Bilthoven, The Netherlands. In Dutch. http://www.rivm.nl/bibliotheek/ rapporten/500799002.html. Cited 13 June 2007

Van Danzig D (1956) Economic decision problems for flood prevention. Econometrica 24:276-287

Van den Brink NGM, Beyer D, Scholten MJM, Van Velzen EH (2007) Onderbouwing Hydraulische Randvoorwaarden 2001 voor de Rijn en zijn takken (Foundation for the Hydraulic Boundary Conditions for the Rhine and its branches). RIZA report 2002.015. Ministry of Transport, Public Works and Water Management, Directorate Rijkswaterstaat, Institute for Inland Water Management and Waste Water Treatment (RIZA), Arnhem, The Netherlands. In Dutch

Van der Most H, Wehrung M (2005) Dealing with uncertainty in flood risk assessment of dike rings in the Netherlands. Nat Hazards 36:191-206

Van Manen SE, Brinkhuis M (2005) Quantitative flood risk assessment for Polders. Reliab Eng Syst Safe 90:229-237

Vrijling JK (2001) Probabilistic design of water defense systems in The Netherlands. Reliab Eng System Safe 74:337-344 